\title{
Rancang Bangun Wastafel dan Portal Otomatis dengan Mempertimbangkan Antropometri Guna Mencegah Penularan COVID19
}

\author{
M. Hanifuddin Hakim ${ }^{1}$, Rudi Irmawanto ${ }^{2}$, Poniman ${ }^{3}$ \\ 1) 2) 3) Fakultas Teknik, Universitas Muhammadiyah Surabaya \\ Email: ${ }^{1)}$ hanifuddinhakim@ft.um-surabaya.ac.id, ${ }^{2)}$ rudi.irmawanto@ft.um-surabaya.ac.id, ${ }^{3)}$ poniman@ft.um- \\ surabaya.ac.id
}

\begin{abstract}
ABSTRAK
Coronavirus yang merajalela pada tahun 2019 (Covid19) mempunyai karakteristik mudah menular, sehingga menjadikan virus ini sangat berbahaya. Meskipun Vaksin sudah ditemukan, protokol kesehatan masih harus diterapkan setidaknya selama 4 tahun kedepan. Salah satu protokol kesehatan yaitu selalu mencuci tangan dengan air mengalir dan sabun. Akan tetapi pada saat mencuci tangan, orang akan tetap menyentuh keran air dan botol sabun, padahal hal ini sangat berpotensi menjadi salah satu media penularan virus. Oleh karena itu penelitian ini bertujuan untuk menghindari sentuhan fisik saat mencuci tangan. Alat ini dilengkapi dengan portal pendeteksi suhu yang berfungi melakukan screening untuk memastikan orang yang akan masuk tidak sedang mengalami demam. Pengembangan teknologi dalam penelitian ini menggunakan metode rancang bangun (research and development). Desain yang dibuat mempertimbangkan Antropometri orang Indonesia. Sehingga Teknologi Tepat Guna (TTG) tersebut dapat memberikan rasa nyaman dan aman saat digunakan. Dari hasil pengujian alat, menunjukkan sensor MLX90614 (temperatur) memiliki tingkat kesalahan rata-rata pengukuran sebesar $0.213^{\circ} \mathrm{C}$ atau sekitar $0.58 \%$, sedangkan sensor PIR (jarak) memiliki tingkat sukses $90 \%$. Secara keseluruhan sistem otomatis pada wastafel dan portal dapat berjalan dengan baik.
\end{abstract}

Kata Kunci : Antropometri, Covid19, Wastafel dan Portal Otomatis

\begin{abstract}
The Coronavirus spread in early 2019 (Covid19) has characteristics of being easily transmitted, making this virus very dangerous. Even though the vaccines has been found, health protocols still have to be implemented for at least the next 4 years. One of the health protocols is washing hands with running water and soap. However, when washing hands, people still touch the water tap and soap bottles, even though this could potentially be a virus transmission media. Therefore, this study aims to avoid physical touch when washing hands. This tool is equipped with a temperature detector portal that functions to ensure that people who enter, do not have a fever. The technology development in this research uses research and development methods. The sink design is made considering Indonesian Anthropometry. Thus Appropriate Technology (TTG) can provide a sense of comfort and safety when used. From the test results, it shows that the MLX90614 sensor (temperature) has an average measurement error rate of $0.213^{\circ} \mathrm{C}$ or about $0.58 \%$. while the PIR (distance) sensor has a success rate of $90 \%$. Overall the automatic system on the sink and portal can work well.
\end{abstract}

Keywords: Anthropometry, Automatic Sink and Portal, Covid19

\section{PENDAHULUAN}

COVID-19 merupakan bagian dari keluarga coronavirus yang menyebabkan penyakit yang berpotensi membunuh manusia [1]. Virus ini awalnya ditemukan di Wuhan, Cina, pada akhir Desember 2019 dan cepat menyebar keseluruh dunia [2]. Hingga 26 Januari 2021, sekitar 98.925.221 kasus dikonfirmasi bersama dengan 2.127.294 kematian secara global. Indonesia tercatat kasus konfirmasi positif sebanyak 1.012.350 dan menjadi Negara dengan kasus konfimasi tertinggi di Asia Tenggara.

Beberapa organisasi kesehatan dunia, ahli medis dan ilmuwan telah mencoba untuk mengembangkan obat-obatan dan vaksin untuk mematikan virus ini. Vaksin import yang akan dipakai di Indonesia sudah melewati tahap uji klinis 3 sehingga mendapat izin BPOM serta halal dari MUI. Meskipun proses vaksinisasi nasional mulai berjalan pada akhir Desember, bukan berarti Indonesia langsung terbebas dari covid19. Karena proses vaksinasi memerlukan waktu dari poduksi massal vaksin hingga penyuntikan vaksin secara bertahap ke semua masyarakat Indonesia [3]. Kondisi tersebut memaksa masyarakat global untuk mencari alternatif agar dapat menghentikan rantai penyebaran virus ini selama proses vaksinansi berjalan. Selalu mencuci tangan, Physical distancing (Jaga jarak) 1 - 
1.5 meter, memakai masker merupakan langkahlangkah menghentikan penyebaran pandemi ini [[4].

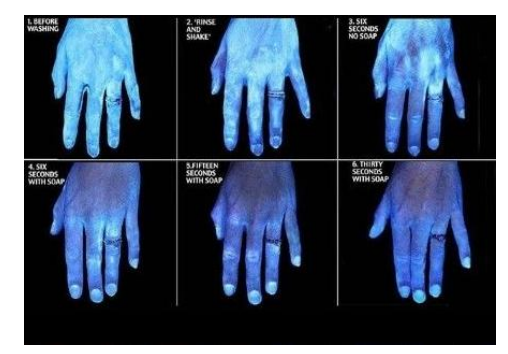

Gambar 1 Efektifitas cuci tangan 20 detik

Virus ini menular melalui media langsung dan tidak langsung. Penularan secara langsung melalui droplet orang yang terjangkit covid19 (percikan saat berbicara, batuk, dan bersin) yang terhirup oleh orang lain sehingga virus masuk ke saluran pernafasan. Sedangkan penularan secara tidak langsung karena droplet terjangkit covid19 menempel pada permukaan benda-benda disekitarnya. Orang yang menyentuh benda tersebut akan terjangkit jika menyentuh mata, mulut, dan hidung [[5]. Oleh karena itu dalam mencegah penyebarannya, masyarakat dihimbau untuk selalu disiplin menerapkan protokol kesehatan, diantaranya dengan mencuci tangan dengan benar, memakai masker, membatasi aktivitas di luar rumah, menghindari kerumunan, melakukan physical distancing, diikuti dengan proses belajar, bekerja, dan beribadah di rumah serta melakukan disinfeksi permukaan benda yang diduga terinfeksi oleh virus corona. Pada gambar 1 menunujukkan efektifitas membunuh kuman dan virus dengan mencuci tangan memakai sabun dan air mengalir selama 20 detik.

Awal tahun 2020, penelitian-penelitian mengenai teknologi otomatis dan digital berkembang relatif cepat, guna merespon penyebaran Covid-19. Saputra dkk [[6] membuat rancang bangun alat pendeteksi temperatur tubuh otomatis menggunakan thermo gun dan melakukan tracking wajah terhadap orang yang memasuki bilik pemeriksaan. Jika suhu melebihi batas-atas maka alarm yang dihasilkan dari buzzer akan berbunyi untuk memberikan peringatan. Febriansyach dkk [7] membuat rancang bangun alat cuci tangan otomatis dengan menggunakan arduiono uno. Penelitian ini berusaha menggunakan sumber energi panas matahari, tapi tidak dapat berjalan optimal. Sedangkan Hasani [8] membuat alat bantu cuci tangan otomatis untuk tuna netra. Penelitian ini bertujuan untuk memudahkan penyandang disabilitas (tuna netra) untuk mencuci tangan di tengah pandemi covid19. Akan tetapi penelitian ini tidak menyertakan rancangan desain visual alat bantu cuci tangan, sehingga para penyandang tuna netra tidak perlu repot menemukan sensor pada alat tersebut. Rahayuningtyas dkk [9] membuat hand sanitizer otomatis dengan sistem monitoring jarak jauh. Penelitian ini mengintegrasikan sensor suhu dan sensor ultrasonik untuk membuat sistem otomatis pada alat ini. Penelitian ini juga mengkombinasikan dengan perangkat wifi untuk melakukan sistem monitoring.

Penelitian-penelitian terdahulu terkait sistem cuci tangan otomatis belum ada yang mengintegrasikan dengan screening suhu/temperatur yang terintegrasi dengan sistem portal otomatis. Padahal sistem portal otomatis pendeteksi suhu ini dapat menjadi screening awal bagi orang yang baru masuk ke suatu tempat. Sehingga orang yang mengalami gejala demam atau sakit tidak diperkenankan masuk ke area tertentu. Penelitianpenelitian sebelumnya juga tidak mempertimbangkan aspek kenyamanan dan keamanan dalam merancang desain alatnya. Sehingga besar kemungkinan orang yang melakukan aktifitas cuci tangan tidak nyaman berlama-lama untuk mencuci tangan. Padahal rekomendasi dari WHO, mencuci tangan dengan air sabun mengalir sekitar 50-60 detik [10].

Dalam penelitian ini, peneliti akan membuat Teknologi Tepat Guna (TTG) otomatis berupa wastafel dan portal otomatis pendeteksi temperatur. Alat tersebut dapat ditempatkan disetiap pintu masuk fasilitas umum agar setiap pendatang melalui screening temperatur dan wastafel otomatis. Suhu normal tubuh manusia dewasa berada pada rentang 36.5-37.5 derajat celcius [11]. Apabila temperatur tubuh berada direntang tersebut, maka portal akan membuka, tetapi jika temperatur tubuh diluar rentang tersebut, maka portal tidak akan membuka.

Harapannya dengan TTG otomatis ini, dapat memudahkan pihak yang berwenang di fasilitas umum, perkantoran, dan pusat perbelanjaan untuk melakukan pengawasan terhadap tamu, karyawan, mahasiswa, dan pengunjung yang melakukan aktivitas di area umum agar tetap disiplin menerapkan protokol kesehatan.

\section{METODOLOGI}

Model yang dikembangkan dalam penelitian ini menggunakan model yang telah dikembangkan oleh Borg dan Gall seperti pada bagan versi Endang Mulyatiningsih [12].

\section{Prosedur Pengembangan}

Pengembangan teknologi dalam penelitian ini menggunakan metode rancang bangun (research and development). Menurut Pressman [13] tahapan yang harus dilalui adalah analisis, desain, implementasi dan pengujian. 


\section{Analisis}

Tahap analisis merupakan tahap untuk mengidentifikasi dan mendapatkan data mengenai kebutuhan yang diperlukan dalam perancangan, penerapan sistem dan pemikiran untuk perancangan selanjutnya.

- Analisis kebutuhan pemakai merupakan analisis mengenai kebutuhan apa saja yang dibutuhkan oleh pemakai yang harus diterapkan pada sistem yaitu antara lain pemantauan temperatur badan saat memasuki AUM dan cuci tangan.

- Analisis kerja merupakan analisis perancangan sistem mengenai data unjuk kerja yang akan dilakukan.

- Analisis data merupakan analisis mengenai kebutuhan data yang akan diproses baik sebagai masukan maupun sebagai keluaran.

- Analisis teknologi merupakan analisis mengenai perangkat teknologi yang akan dipakai dalam sistem yang akan dirancang.

\section{Desain}

Desain adalah tahapan untuk mendapatkan cara paling efektif dan efisien untuk mengimplementasikan sistem dengan bantuan data yang diperoleh dalam tahap analisis. Tahapan dalam desain sebagai berikut:

- Desain visual alat menggunakan data antropometri dimensi tubuh orang Indonesia secara umum menurut Nurmianto [14]. Antropometri digunakan untuk menentukan dimensi dari peralatan, tempat kerja, furniture, dan pakaian. Tujuannya adalah untuk memenuhi kebutuhan manusia, sehingga manusia merasa nyaman saat menggunakan.

- Desain umum sistem mekanik yang terdiri dari sensor MLX90614 (sensor temperatur), Sensor PIR (sensor jarak), LCD, motor servo, portal, modul kontroler, dan Arduino uno.

- Desain rangkaian elektronik yang akan digunakan dalam pembuatan hardware sistem teknologi otomatis berbasis arduino uno (mikrokontroler)

- Desain diagram alir program yang menggambarkan urutan proses dan hubungan antara proses secara detail di dalam program.

\section{Penerapan}

Menentukan program source code yang dibutuhkan sebagai elemen pendukung program yang telah dirancang ke mikrokontroler arduino di modul teknologi otomatis. Merakit komponen elektronik yang dirancang, sesuai desain rangkaian elektronik yang telah dibuat. Langkah berikutnya, menyatukan prosedur, subrutin dan fungsi dari modul-modul yang telah dibuat ke dalam kesatuan program.

\section{Pengujian}

Pengujian dilakukan untuk memastikan apakah sistem yang telah dibuat sesuai dengan hasil dari analisis kebutuhan. Pengujian yang dilakukan terbagi dari dua tahapan, yaitu pengujian hardware dan pengujian software. Pengujian hardware dilakukan dengan cara mengaktifkan sensor MLX90614 untuk mengukur temperatur orang dengan alat ukur [15], kemudian dibandingkan, apakah hasil tampilan monitoring masih dalam batas toleransi yang ditetapkan WHO yaitu $36.5-37.5{ }^{\circ} \mathrm{C}$. Bila sinyal output mempunyai hasil diatas batas yang ditetapkan, maka portal tetap dalam kondisi tertutup dan LCD akan menampilkan temperatur suhunya. Sedangkan wastafel otomatis menggunakan sensor PIR (jarak), apabila terdeteksi adanya objek pada jarak yang ditentukan, maka relay akan aktif untuk menghidupkan kran air dan sabun [16].

Pengujian software merupakan proses eksekusi pada program untuk menemukan kesalahan program yang sudah dibuat. Sebelum program diterapkan, maka program harus bebas terlebih dahulu dari temuan kesalahan (error). Pengujian dilakukan pada setiap modul dan dilanjutkan dengan pengujian pada semua modul yang telah dirangkai sebelumnya. Terdapat dua jenis rancangan pengujian software yaitu White Box Testing dan Black Box Testing. White Box Testing adalah rancangan pengujian menggunakan struktur kontrol perancangan prosedural. Sedangkan Black Box Testing adalah rancangan pengujian dengan cara menguji beberapa aspek sistem dengan sedikit memperhatikan struktur logika internal software. Pengujian ini akan memperlihatkan fungsi software beroperasi saat input diterima maka output benar. Kedua jenis rancangan pengujian tersebut bersifat komplementer.

\section{HASIL DAN PEMBAHASAN}

Hasil penelitian merupakan pengembangan modul perangkat keras dan perangkat lunak. Perangkat keras yang berhasil dirakit untuk sistem otomatis wastafel dan portal pendeteksi temperatur ini terdiri dari sensor MLX90614, sensor jarak (PIR), motor servo, lcd, mikrokontroler Arduino Uno, dan perangkat komputer/laptop.

\section{Desain}

Desain visual alat berdasar data antropometri dimensi orang Indonesia secara umum, sumber data diambil dari pakar ergonomi untuk mengetahui dimensi tubuh manusia. Variabel dimensi tubuh yang dipakai sesuai kebutuhan alat yang akan dirancang. Berikut data variabel yang dipakai dan dimensinya: 
RESISTOR (Elektronika Kendali Telekomunikasi Tenaga Listrik Komputer) Vol. 4 No. 1 e-ISSN : 2621-9700, p-ISSN : 2654-2684

Tabel 1 Data antropometri (satuan $\mathrm{cm}$ )

\begin{tabular}{|c|c|c|c|c|c|c|c|c|}
\hline \multirow{2}{*}{ Dimensi tubuh } & \multicolumn{4}{|c|}{ Pria } & \multicolumn{4}{c|}{ Wanita } \\
\cline { 2 - 10 } & $5 \%$ & $\mathrm{X}$ & $95 \%$ & S.D & $5 \%$ & $\mathrm{X}$ & $95 \%$ & S.D \\
\hline Tinggi bahu* & 125 & 134 & 142.9 & 5.5 & 118 & 127 & 136.1 & 5.4 \\
\hline $\begin{array}{c}\text { Tinggi } \\
\text { pinggul** }\end{array}$ & 89.2 & 95 & 100.7 & 3.5 & 83.8 & 92 & 100.2 & 4.9 \\
\hline $\begin{array}{c}\text { Panjang } \\
\text { tangan* }\end{array}$ & 16.1 & 17.6 & 19.1 & 0.9 & 15.3 & 16.8 & 18.3 & 0.9 \\
\hline Lebar bahu* & 38.2 & 42.4 & 46.6 & 2.6 & 34.2 & 38.5 & 42.8 & 2.6 \\
\hline $\begin{array}{c}\text { Tebal telapak } \\
\text { tangan* }\end{array}$ & 4.1 & 4.8 & 4.7 & 0.2 & 4.1 & 4.4 & 4.7 & 0.2 \\
\hline
\end{tabular}

Sumber: [14] dan antropometri indonesia**

Alat ini akan ditempatkan di fasilitas umum, perkantoran, perbelanjaan, dan lembaga-lembaga umum lainnya. Sehingga sasaran yang akan memakai alat ini adalah masyarakat luas, tanpa mengesampingkan jenis kelamin. Pemakainya juga berada diusia produktif antara 17-55 tahun. Agar alat ini dapat mengakomodir masyarakat umum, maka data antropometri yang dipakai adalah wanita, karena agar dapat dijangkau pria \& wanita dari segi tinggi maupun panjang tangan.

Pada tabel 1, angka 5\% (persentil 5) yang memiliki arti pengukuran dimensi tubuh untuk mewakili nilai populasi minimum, $\mathrm{X}$ menunjukkan pengukuran rata-rata dari populasi, angka 95\% (persentil 95) yang memiliki arti pengukuran dimensi tubuh untuk mewakili nilai populasi maksimal, sedangkan S.D adalah standar deviasi.

Untuk dimensi tinggi pinggul dan panjang tangan dipilih persentil 5 agar keran air dapat dijangkau populasi minimal. Sedangkan tinggi bahu, lebar bahu, dan tebal telapak tangan dipakai pengukuran rata-rata agar dapat memberikan rasa kenyamanan pada populasi mayoritas saat proses memindahkan tangan dari aktivitas memakai keran air sabun dengan keran air bersih. Berikut gambar 2 desain visual alat hasil penerapan antropometri.

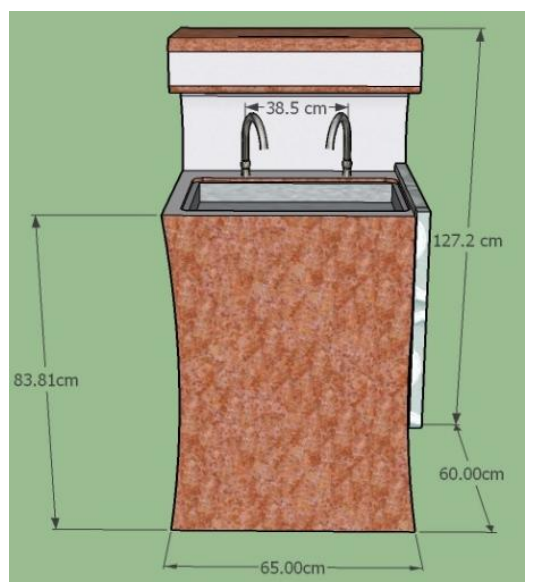


RESISTOR (Elektronika Kendali Telekomunikasi Tenaga Listrik Komputer) Vol. 4 No. 1 e-ISSN : 2621-9700, p-ISSN : 2654-2684

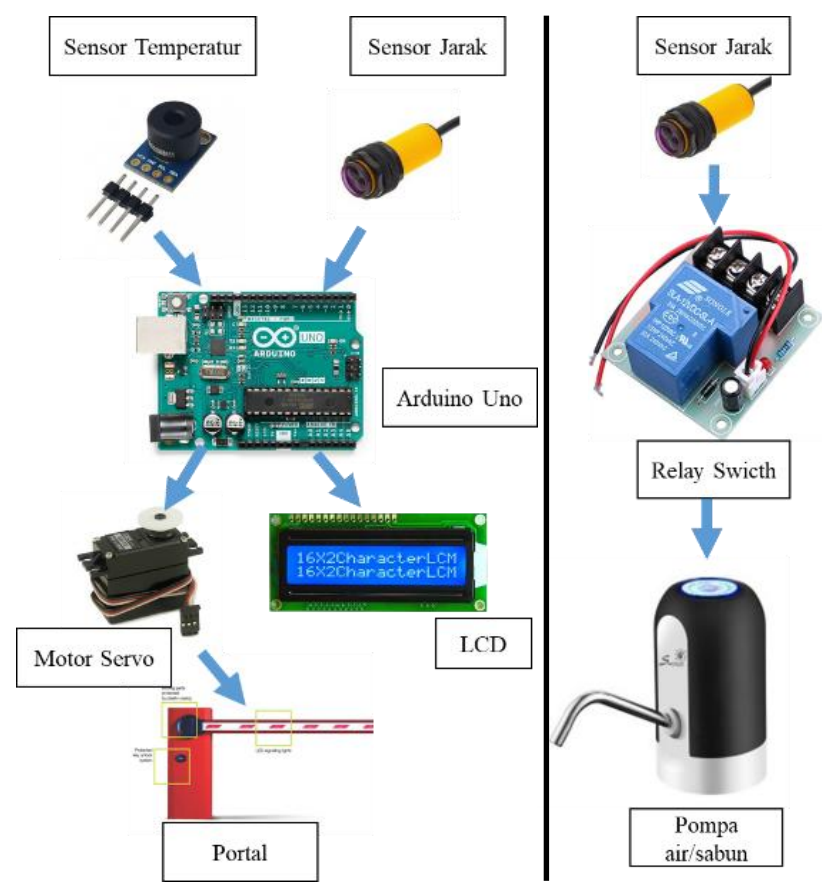

Gambar 4 Blok diagram sistem wastafel \& portal otomatis

Pada gambar 4 tersebut menunjukkan blok diagram sistem otomatis dari wastafel dan portal. Pada sistem portal otomatis, sensor temperatur (MLX90614) digunakan untuk memperoleh data temperatur orang yang akan masuk area. Hasil pembacaan diubah menjadi tegangan analog yang dijadikan data masukan pada mikrokontroler Arduino uno. Mikrokontroler Arduino digunakan untuk mengolah data sensor MLX90614. Jika data menunjukkan temperatur diantara $36.5-37.5{ }^{\circ} \mathrm{C}$ maka arduino akan mengaktifkan motor servo untuk membuka portal. Akan tetapi jika data menunjukkan temperatur diluar $36.5-37.5^{\circ} \mathrm{C}$. maka arduino tidak memberikan sinyal ke motor servo.

Sedangkan sistem wastafel otomatis terdiri dari komponen sensor jarak yang berfungsi untuk mendeteksi ada objek (tangan) atau tidak di dekatnya. Jika ada objek yang terdeteksi maka sinyal sensor akan mengaktifkan relay switch dan menyalakan pompa air. Apabila benda sudah tidak terdeteksi maka relay switch akan mematikan pompa air.

\section{Flowchart dan Algoritma}

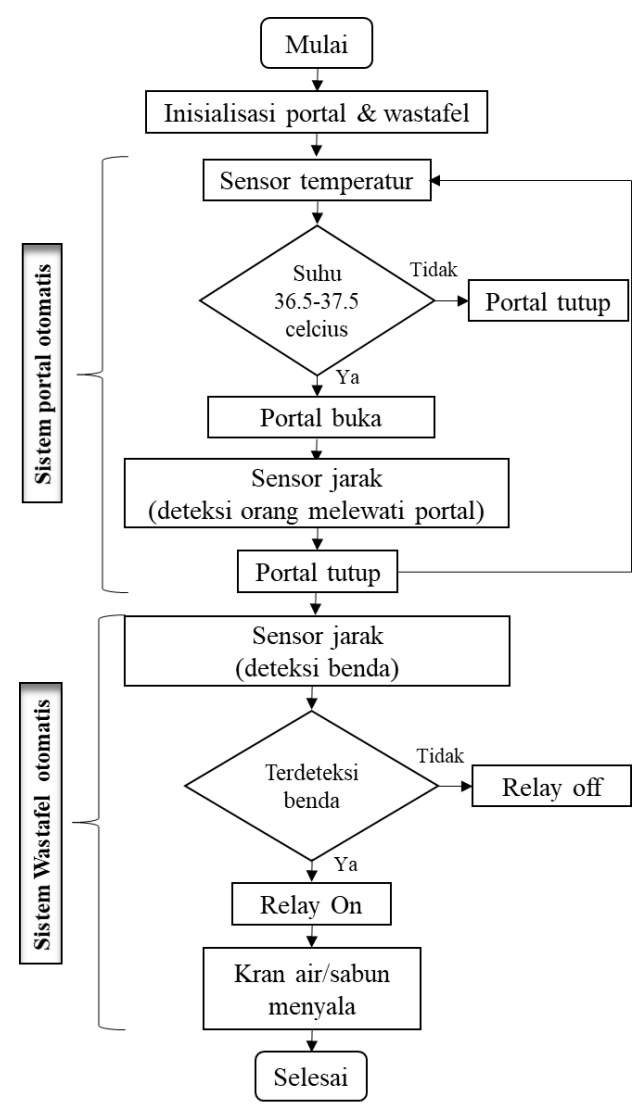

Gambar 5 Flowchart berikut:

Penjelasan Flowchart pada gambar 5 sebagai

- Alat dihidupkan

- Inisialisasi port guna mendefinisikan pin I/O mikrokontroller yang digunakan pada rangkaian alat

- Sensor temperatur (MLX90614) akan membaca temperatur tubuh orang mendekat

- Apakah orang yang berada didepan portal memiliki suhu tubuh antara $36.5-37.5^{\circ}$ celcius?

- Jika iya maka portal akan terbuka

- Jika tidak maka portal akan tetap tertutup

- Sensor jarak pada portal akan mendeteksi jika ada orang yang melewati portal serta mengirimkan sinyal untuk menutup portal kembali.

- Pada sistem wastafel otomotasi. Sensor jarak yang terletak didekat kran. akan mendeteksi jika ada objek (tangan) yang ada dijangkauannya.

- Jika iya maka Relay switch akan on

- Jika tidak maka Relay switch akan tetap off

- Relay Switch hidup akan mengaktifkan kran air dan kran sabun

- Selesai

Pengujian dan Pembahasan 
RESISTOR (Elektronika Kendali Telekomunikasi Tenaga Listrik Komputer) Vol. 4 No. 1 e-ISSN : 2621-9700, p-ISSN : 2654-2684

Dalam pengujian ini terdiri dari 2 tahapan. yaitu: pengujian alat secara keseluruhan dan pengujian komponen. Pengujian alat secara keseluruhan dilakukan skenario sebagai berikut:

\section{Pengujian Mikrokontroler}

Pengujian mikrokontroler yang bertujuan untuk mengetahui fungsi dari mikrokontroler apakah sudah berjalan atau tidak. Seperti yang ditampilkan seperti pada gambar 6 berikut:

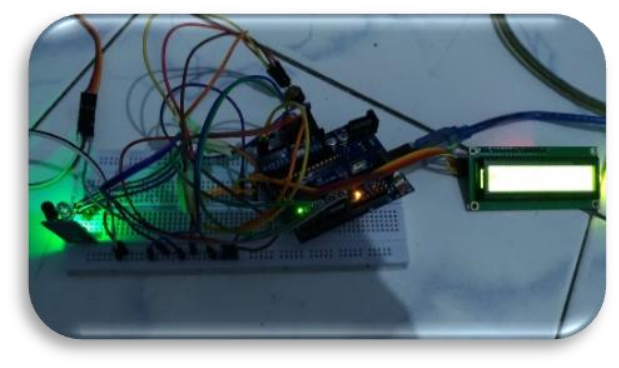

Gambar 6. Pengujian mikrokontroler

\section{Pengujian LCD}

Proses pengujian LCD untuk menampilkan baris atas dan baris bawah seperti yang ditunjukkan pada gambar 7 berikut:

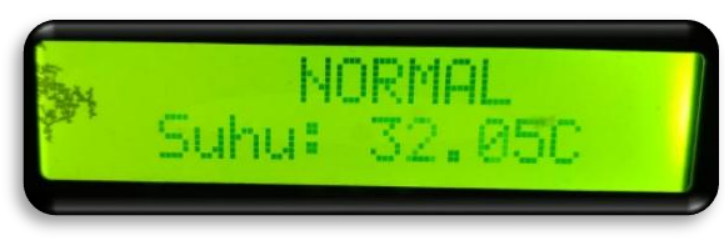

\section{Gambar 7. Pengujian LCD}

\section{Pengujian motor servo}

Proses pengujian motor servo untuk membentuk sudut $90^{\circ}$ yang menunjukkan bahwa portal dalam keadaan tertutup. Seperti yang ditampilkan seperti pada gambar 8 berikut:

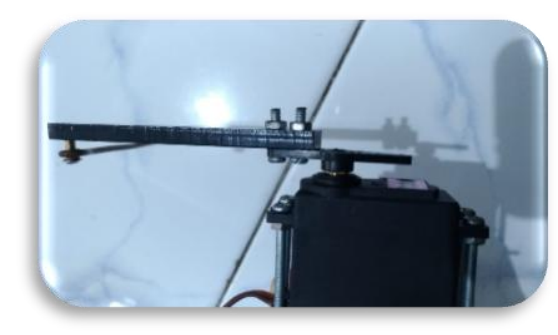

Gambar 8. Pengujian motor servo

\section{Pengujian Sensor Temperatur}

Sensor temperatur diuji untuk mengetahui apakah sensor dapat membaca temperatur badan

dengan akurasi yang baik. Hasil pengujian pengukuran suhu dengan sensor MLX90614 dan thermogun ditunjukkan dalam Tabel 3 berikut:

Tabel 2 Tabel hasil pengujian temperatur

\begin{tabular}{|c|c|c|c|c|}
\hline \multirow{2}{*}{ No } & \multirow{2}{*}{$\begin{array}{c}\text { Data Suhu } \\
\text { MLX90614 }\left({ }^{\circ} \mathrm{C}\right)\end{array}$} & \multirow{2}{*}{$\begin{array}{c}\text { Data Suhu } \\
\text { Thermogun }\left({ }^{\circ} \mathrm{C}\right)\end{array}$} & \multicolumn{2}{|c|}{ Selisih } \\
\cline { 4 - 6 } & & $\left({ }^{\circ} \mathrm{C}\right)$ & $\%$ \\
\hline 1 & 36.65 & 36.5 & 0.15 & $0.41 \%$ \\
\hline 2 & 37.24 & 37.1 & 0.14 & $0.38 \%$ \\
\hline 3 & 36.98 & 36.8 & 0.18 & $0.49 \%$ \\
\hline 4 & 36.72 & 36.5 & 0.22 & $0.60 \%$ \\
\hline 5 & 37.44 & 37.2 & 0.24 & $0.65 \%$ \\
\hline 6 & 37.01 & 36.8 & 0.21 & $0.57 \%$ \\
\hline 7 & 37.27 & 37 & 0.27 & $0.73 \%$ \\
\hline 8 & 37.12 & 36.9 & 0.22 & $0.60 \%$ \\
\hline 9 & 37.36 & 37.2 & 0.16 & $0.43 \%$ \\
\hline 10 & 37.24 & 36.9 & 0.34 & $0.92 \%$ \\
\hline \multicolumn{3}{|c|}{ Tingkat error } & 0.213 & $0.58 \%$ \\
\hline
\end{tabular}

Berdasarkan tabel 2 menunjukkan hasil pengujian temperatur menggunakan sensor MLX90614 dibandigkan dengan thermogun dapat diketahui bahwa error rata-rata pengukuran adalah sebesar $0.213^{\circ} \mathrm{C}$ atau sekitar $0.58 \%$. Error minimum pengukuran tercatat sebesar $0.38 \%$ dan error maksimum pengukuran tercatat sebesar $0.92 \%$.

\section{Pengujian Sistem Wastafel}

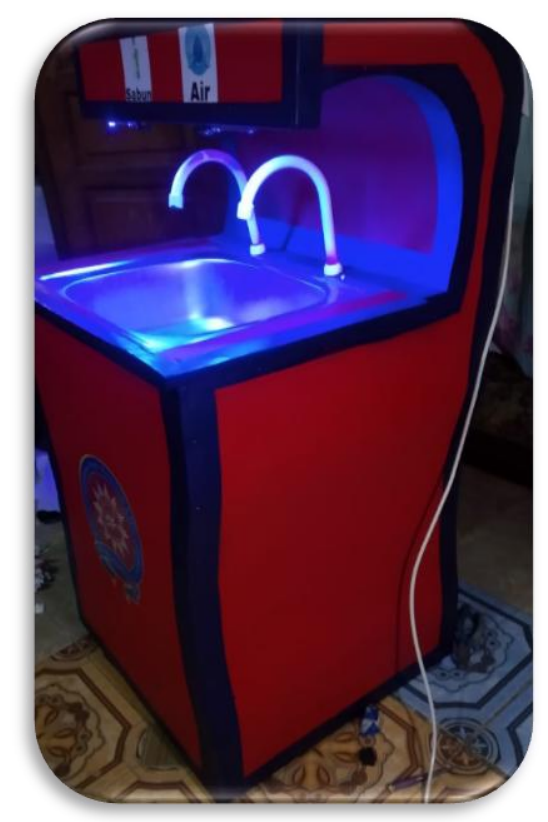

Gambar 9. Wastafel otomatis

Gambar 9 merupakan hasil pembuatan wastafel otomatis sesuai dengan desain yang telah dibuat. 
RESISTOR (Elektronika Kendali Telekomunikasi Tenaga Listrik Komputer) Vol. 4 No. 1 e-ISSN : 2621-9700, p-ISSN : 2654-2684

Sistem westafel otomatis menggunakan sensor PIR. Agar sistem otomatis dapat berjalan dengan baik maka sensor PIR harus melalui tahap uji. Sensor PIR (sensor jarak) diuji untuk mengetahui seberapa baik sensor mendeteksi adanya objek dengan jarak yang telah ditentukan. Sensor diletakkan diatas penutup keran. Sensor telah diatur agar dapat mendeteksi objek (tangan) dalam jangkauan $30 \mathrm{~cm}$. Jika sensor mendeteksi adanya objek, maka sensor akan mengaktifkan relay, sehingga pompa air akan menyala. Hasil pengujian pengukuran sensor PIR ditunjukkan dalam Tabel 3 berikut:

Tabel 3 Tabel hasil pengujian sensor

\begin{tabular}{|c|c|c|c|}
\hline Pengujian & $\mid \begin{array}{c}\text { Jarak objek } \\
(\mathrm{cm})\end{array}$ & Sensor PIR & Keterangan \\
\hline 1 & 27 & Aktif & Kondisi baik \\
\hline 2 & 27.5 & Aktif & Kondisi baik \\
\hline 3 & 28 & Aktif & Kondisi baik \\
\hline 4 & 28.5 & Aktif & Kondisi baik \\
\hline 5 & 29 & Aktif & Kondisi baik \\
\hline 6 & 29.5 & Aktif & Kondisi baik \\
\hline 7 & 30 & Aktif & Kondisi baik \\
\hline 8 & 30.5 & Aktif & Kondisi gagal \\
\hline 9 & 31 & Tidak aktif & Kondisi baik \\
\hline 10 & 31.5 & Tidak aktif & Kondisi baik \\
\hline \multicolumn{3}{|c|}{ Tingkat keberhasilan } & $90 \%$ \\
\hline
\end{tabular}

Dari hasil pengujian yang ditunjukkan tabel 3, tingkat keberhasilan sensor jarak mendeteksi dengan rentang $30 \mathrm{~cm}$ adalah $90 \%$. Meskipun ada sekali pengujian yang gagal, saat jarak $30.5 \mathrm{~cm}$, akan tetapi sistem wastafel tetap berjalan dengan baik.

\section{Hasil pengujian}

Hasil pengujian alat secara keseluruhan dan pengujian komponen adalah alat dapat bekerja dengan baik dan sesuai dengan rancangan diawal. Sistem portal otomatis dapat berjalan dengan dengan baik. Jika ada orang yang memiliki temperatur melebihi $37.5^{\circ} \mathrm{C}$ maka portal akan tetap menutup. Begitu juga dengan sistem wastafel otomatis, juga dapat berjalan dengan baik. Meskipun pengujian keberhasilannya tidak mencapai $100 \%$, akan tetapi sistem wastafel otomatis masih tetap dapat berjalan

\section{KESIMPULAN}

Dalam pembuatan rancang bangun ini telah dibuat suatu prototype alat portal dan wastafel otomatis. Dari pembuatan Teknologi Tepat Guna (TTG) tersebut diharapkan dapat digunakan dan diterapkan pada fasilitas umum dan tempat-tempat dengan aktifitas padat guna mencegah penularan

Covid19. Teknologi tersebut juga bertujuan untuk mempermudah masyarakat umum dalam menjalankan aktivitasnya ditengah pandemi dengan tetap disiplin menerapkan protokol kesehatan yang ketat.

\section{UCAPAN TERIMA KASIH}

Penulis mengucapkan terimakasih kepada Majelis Dikti Litbang PP Muhammadiyah yang telah memberikan pendanaan melalui program hibah risetMU batch 4 serta pendampingan selama proses penyelesaian penelitian ini.

\section{DAFTAR PUSTAKA}

[1] Wu, Zhao, Y. B, and E. Al., "A new coronavirus associated with human respiratory diseases in China," Nature, vol. 579, no. 265, p. $9,2020$.

[2] Zhou et al., "A pneumonia outbreak associated with a new coronavirus of probable bat origin. . 2020;," Nature, vol. 579, pp. 270-3, 2020.

[3] I. P. Sari and S. Sriwidodo, "Perkembangan Teknologi Terkini dalam Mempercepat Produksi Vaksin COVID-19," Maj. Farmasetika, vol. 5, no. 5, p. 204, 2020, doi: 10.24198/mfarmasetika.v5i5.28082.

[4] Y. Triguno, P. L. Ayu, K. E. L. Wardana, N. M. Raningsih, and K. D. Arlinayanti, "Jurnal Peduli Masyarakat," J. Peduli Masy., vol. 2, no. September, pp. 59-64, 2020.

[5] A. Athena, E. Laelasari, and T. Puspita, "Pelaksanaan Disinfeksi Dalam Pencegahan Penularan Covid-19 Dan Potensi Risiko Terhadap Kesehatan Di Indonesia," J. Ekol. Kesehat., vol. 19, no. 1, pp. 1-20, 2020, doi: 10.22435/jek.v19i1.3146.

[6] A. Saputra, M. Ansori, and D. Widiatmoko, "Rancang bangun alat pendeteksi suhu tubuh otomatis dengan image processing menggunakan metode backropagation," 2020.

[7] R. Febriansyach, D. B. Santoso, U. Latifa, and S. Karawang, "Portable Dengan Teknologi Mikrokontroler Arduino Uno Design of Portable Automatic Hand Washer With," vol. 6, no. 2, 2020.

[8] M. C. Hasani, "PENGEMBANGAN ALAT BANTU CUCI TANGAN OTOMATIS BAGI PENYANDANG DISABILITAS SEBAGAI UPAYA PENCEGAHAN DINI PENYEBARAN COVID-19," pp. 66-70, 2020. 
RESISTOR (Elektronika Kendali Telekomunikasi Tenaga Listrik Komputer) Vol. 4 No. 1 e-ISSN : 2621-9700, p-ISSN : 2654-2684

[9] A. Rahayuningtyas et al., "DESIGN AND IMPLEMENTATION OF AUTOMATIC HAND SANITIZER AND," pp. 320-330, 2020.

[10] WHO, on Hand Hygiene in Health Care: a Summary First Global Patient Safety Challenge Clean Care is Safer Care. Switzerland: University of Geneva Hospitals and Faculty of Medicine, 2009.

[11] I. T. Yuniahastuti, I. Sunaryantiningsih, and B. Olanda, "Contactless Thermometer sebagai Upaya Siaga Covid-19 di Universitas PGRI Madiun," vol. 1, no. 1, pp. 28-34, 2020.

[12] Falahuddin, "Respons Muhammadiyah Menghadapi Covid-19," Maarif, vol. 15, pp. 137-152, 2020.

[13] R. S. Pressman, Rekayasa Perangkat Lunak. Yogyakarta: ANDI, 2002.

[14] E. Nurmianto, Ergonomi, Konsep Dasar dan Aplikasi (II). Surabaya: Guna Widya, 2005.

[15] S. Yatmono and Dkk, "Rancang bangun sistem monitoring suhu dan kelembaban berbasis labview dan android," Yogyakarta, 2017.

[16] S. Ahadiah, Muharnis, and Agustiawan, "Implementasi Sensor PIR pada Peralatan Elektronik Berbasis Mikrokontroler," $J$. Invotek Polbeng, vol. 07, no. 1, pp. 29-34, 2017. 